\title{
Mit kosowski we współczesnej serbskiej myśli nacjonalistycznej
}

\section{WPROWADZENIE}

\section{$\mathrm{M}$} ITY NADAL WYWIERAJĄ OGROMNY WPŁYW na kształtowanie się poglądów całych społeczeństw, stąd też tematem artykułu będzie obecność mitu kosowskiego we współczesnej serbskiej myśli nacjonalistycznej. Mity są narzędziem, z którego chętnie korzystają zarówno przedstawiciele sceny politycznej, jak i środowiska opiniotwórcze. Dlatego zadaniem artykułu będzie dokonanie analizy obecności wybranego mitu związanego z Kosowem, zarówno w warstwie politycznej, jak i w świadomości zwolenników partii nacjonalistycznych. Do przeprowadzenia badań wykorzystano elementy reprezentujące serbską kulturę popularną, takie jak teksty piosenek oraz mając na uwadze utrzymującą się stale tendencję kierowania się mitem jako argumentem usprawiedliwiającym działania, fragmenty przemówienia wygłoszonego przez jednego z najważniejszych polityków serbskich - Slobodana Miloševicia. Dokonując analizy badaniom poddano także tekst Nikolaja Veimirovicia Nacjonalizam svetoga Save, uznawany za kamień węgielny serbskiej myśli nacjonalistycznej. Do badań posłużyły także inne wybrane teksty umożliwiające obserwację rozwoju mitu kosowskiego. Za najbardziej przydatne uznano źródła historyczne dotyczące bitwy na Kosowym Polu, które m.in. zestawiono z epickimi pieśniami ludowymi zebranymi w cyklu kosowskim. Głównym problemem badawczym artykułu jest charakter występowania mitu kosowskiego wśród zwolenników serbskiej myśli nacjonalistycznej. Jako hipotezę przyjęto często wykorzystywaną w rozmaitych kontekstach obecność tego mitu jako ważnego elementu współczesnej serbskiej polityki, w oparciu o który Republika Serbii stara się budować swoją narodową tożsamość.

Mity i ich występowanie to kwestia bardzo złożona. Nawet zawężenie jej do jednej tylko mitycznej historii, wykorzystywanej przez jeden tylko naród, nie pozwala na całkowite wyczerpanie tematu. Wybrane przykłady obecności mitu kosowskiego w serbskiej myśli nacjonali- 
stycznej stanowią zaledwie punkt wyjścia do dalszych rozważań. Czym jest mit w myśli politycznej?

Mit jest złożonym zjawiskiem kulturowym, które można interpretować na wielu płaszczyznach. Wraz z początkiem XX w. przestał on być rozumiany jako „baśń”, „zmyślenie”, „fikcja”, a zyskał znaczenie przeciwne, stając się „historią prawdziwą”, która ma niezwykłą wartość, jest święta i pouczającaํ. Tracąc swoją jednoznaczność mit utracił także możliwość definiowania go w jednolity sposób². Badacz mitów Mircea Eliade określił mit jako „historię świętą, opisującą wydarzenie, które miało miejsce w okresie wyjściowym, legendarnym czasie początków”, podkreślając jednocześnie, że definicja ta jest w dużej mierze niedoskonała ${ }^{3}$.

Przyglądając się mitom możemy zauważyć, że wszystko, co w nich opisano dotyczy bezpośrednio ludzi i najważniejszych wydarzeń, które sprawiły, że człowiek stał się tym, kim jest obecnie ${ }^{4}$. Mit pozwala poznać tajemnicę początków rzeczy, wyjaśnia, w jaki sposób zaczęły one istnieć i mówi, gdzie ich szukać, aby pojawiły się ponownie, jeśli z jakichś względów zaginą5. Mit posiada szereg charakterystycznych cech. Może on być historią uznawaną za całkowicie prawdziwą (odnoszącą się do faktów) i jednocześnie świętą (będącą dziełem istot nadprzyrodzonych). Mit odnosi się do stworzenia lub końca świata ${ }^{6}$. Warte uwagi są tu mity kosmogoniczne i estachologiczne, których aktorami są istoty boskie, nadnaturalne lub niebiańskie, czy też mity o przygodach narodowych bohaterów, nisko urodzonych ludzi, którzy wybawili swój lud od potworów, wydobyli z głodu, bądź też w inny sposób stali się jego wybawcami . Wreszcie, dla każdego z nas, mit stanowi historię, którą ,żyjemy”, która jest dominującą nad nami potęgą sławiącą przypominane i ponawiane wydarzenia ${ }^{8}$. Należy jednak pamiętać, idąc za słowami Bronisława Malinowskiego, że mitu nie należy traktować

${ }^{1}$ M. Eliade, Aspekty mitu, Warszawa 1998, s. 7.

${ }^{2}$ L. Kołakowski uogólnienie pojęcia mitu uznaje za jak najbardziej usprawiedliwione, bowiem z perspektywy filozoficznej lepiej jest rozszerzać zakres pojęć istniejących niż tworzyć nowe, abstrakcyjne twory. L. Kołakowski, Obecność mitu, Warszawa 2005, s. 8-9.

${ }^{3}$ M. Eliade, op. cit., s. 11.

${ }^{4}$ Ibidem, s. 16-17.

5 Ibidem, s. 19.

${ }^{6}$ Ibidem, s. 23-24.

7 Ibidem, s. 14.

8 Ibidem, s. 24. 
jako sposobu naukowego objaśniania rzeczywistości甲 ${ }^{9}$, ani jako naiwnej formy propagowania wiedzy o świecie.

Nie można interpretować mitu jako tekstu poza kulturą, w której funkcjonuje, czy też w oderwaniu od sytuacji wywierającej na niego bezpośredni wpływ. O tożsamości mitu przesądza bowiem rola, którą odgrywa on w praktyce ${ }^{10}$. Jego głównym zadaniem jest rozwiązywanie problemów fazy „krytycznej”, poprzez stworzenie zarówno nowego języka, za pomocą którego wszyscy mogą się porozumiewać, jak i oferowanie wizji uporządkowanego, zdefiniowanego świata, uwalniając w ten sposób od wątpliwości. Pełnię swoich sił osiąga on w momencie, w którym człowiek musi zmierzyć się z niezwykłą i niebezpieczną dla niego sytuacją. W dzisiejszych czasach, kiedy obserwujemy narastanie bezradności wynikające z zagubienia w skomplikowanej strukturze społeczeństwa często oddajemy się tworzonej przez mity „magii społecznej”, poszukując w niej zrozumienia otaczających nas mechanizmów ${ }^{11}$.W wielu społeczeństwach mit jest ciągle żywy w tym sensie, że dostarcza on wzorców zachowań i jest podstawą oraz uzasadnieniem ludzkich działań m.in. w sferze bieżącej polityki ${ }^{12}$. Człowiek tworzący mit stwarza go kontestując zastany obraz świata lub nie rozumiejąc mechanizmów nim kierujących. Wykorzystuje do tego znaki dostarczane mu przez rzeczywistość, która go bezpośrednio otacza. Wyraża pragnienie zmiany, nie szukając jednak oparcia w argumentacji teoretycznej. W tym ujęciu mit jest swobodną grą wyobraźni, rezygnacją ze sztywnych pojęć i definicji ${ }^{13}$. Takie określanie może prowadzić do wniosku, że motywy działania człowieka tworzącego mit mają charakter pozaracjonalny i pozbawiony reguł celowości. Zaobserwować to można w przypadku zdarzeń o skali masowej. Georges Sorel, uznając mit za osnowę zbiorowej świadomości twierdził, że mit inspiruje wolę czynu oraz przesądza o przebiegu masowych procesów ${ }^{14}$. W swoim rozumowaniu nawiązywał on do koncepcji Gustave'a Le Bona wskazującej, że ,tłum myśli obrazami, a jeden obraz wywołuje u niego szereg nowych obrazów, nie łączących się logicznie z pierwszym" ${ }^{15}$. G. Sorel przyznaje także, że człowiek najchętniej akceptuje

${ }^{9}$ L. Kołakowski próby naśladowania wiedzy przez mit określa jako formę degeneracji wiary, L. Kołakowski, op. cit., s. 15.

${ }^{10} \mathrm{~S}$. Filipowicz, Mit i spektakl władzy, Warszawa 1988, s. 48-49.

${ }^{11}$ Ibidem, s. 77-78.

${ }^{12}$ M. Eliade, op. cit., s. 8-10.

${ }^{13}$ S. Filipowicz, op. cit., s. 73 .

${ }^{14}$ Ibidem, s. 82.

${ }^{15}$ Ibidem. 
to, w co wierzy i daje się ku czemuś przekonać tylko w momencie, gdy perswazja jest już zbędna. Z pozoru logiczna argumentacja, na której opierają się poglądy, okazuje się być w istocie pseudoracjonalizmem ${ }^{16}$. Dla funkcjonowania społeczeństwa kultywowanie mitu ma wiele znaczeń. Pozwala ono na identyfikowanie ze sobą idei politycznych zakładających urzeczywistnienie określonego celu ${ }^{17}$ lub aktualizację pewnego wzoru. Mit zakorzeniony w zbiorowej psychice konkretyzuje pojawiające się wyobrażenia, rozwiewając jednocześnie wątpliwości dotyczące pozytywnego rezultatu podejmowanych przedsięwzięćc ${ }^{18}$, ujawnia definitywną prawdę, likwidując przy tym potrzebę wszelkiej refleksji ${ }^{19}$.

Mity przyczyniają się także do zwiększenia poczucia tożsamości oraz jednoczesnego zmniejszenia swoistej bezradności wynikającej z niezrozumienia świata, a identyfikacja z nimi stanowi źródło głębokiej satysfakcji ${ }^{20}$. Poczucie ciągłości wobec tradycji może sprzyjać świadomości mitycznej. Dziedziczenie mitów jest dziedziczeniem wartości, które mit narzuca. Nie znaczy to wcale, że tradycję należy czcić bez zastrzeżeń, ukazuje jedynie siłę autorytetów pochodzących z poprzednich pokoleń ${ }^{21}$.

Czynnikiem wpływającym na nieustanne kultywowanie mitów jest zapotrzebowanie na historię. To ona odpowiada na pytania o to, skąd pochodzimy, kim jesteśmy i dokąd zmierzamy. Powracamy do tego co minione w celu znalezienia odpowiedzi na pytania dotyczące teraźniejszości stale transmutującej się w przyszłośćc ${ }^{22}$. Zwracanie się ku przeszłości i mityzowanie bądź wypieranie wybranych jej fragmentów potwierdza, że mit jest silny w swoim znaczeniu, lecz słaby w prawdzie. Jak powiedział Ernest Carr „Fakty są święte, ale interpretacja dowolna", co oznacza, że ten sam fakt możemy wykorzystać jednocześnie dla poparcia jak i zanegowania jakiejś tezy. Zaznaczył on także, że przemawiają do nas nie same fakty, ale ci, którzy dokonują ich su-

${ }^{16}$ Ibidem, s. 88 .

${ }^{17}$ Mit może też być groźny, gdyż ma on tendencje do nieograniczonej ekspansji, zaznaczania swojej obecności we wszelkich dziedzinach, a przy tym często zdaje się zwalniać jego propagatorów od odpowiedzialności za ich czyny, L. Kołakowski, op. cit., S. 155 .

\footnotetext{
${ }^{18}$ Ibidem, s. 92.

${ }^{19}$ Ibidem, s. 22.

${ }^{20}$ Ibidem, s. 112.

${ }^{21}$ Ibidem, S. 21-22.

${ }^{22}$ S. Filipowicz, op. cit., s. 28-29.
} 
biektywnej selekcji ${ }^{23}$. Politycy są, jak określił ich Ernst Cassirer, wytwórcami mitów niezwykle biegłymi w swojej sztuce ${ }^{24}$. Umiejętnie aranżują oni odpowiednie sytuacje wykorzystując nastroje i pragnienia przesądzające o ludzkiej postawie. Nie tworzą oni mitów w sposób dowolny - stosując polityczną filtrację arbitralnie wyodrębniają je ze zbioru istniejącego od najdawniejszych czasów, nadając im aktualny sens polityczny, szacowny rodowód i rozbudowane koneksje. W ten sposób powstają mity określane jako rewolucyjne, które są podparciem idei gwałtownych przemian. Mit polityczny czasem zastępuje myślenie, czasem zaś staje się jego podstawą lub dopełnieniem ${ }^{25}$. Według Rolanda Barthesa mit to „słowo zdepolityzowane”, czyli pozbawione właściwości historycznych, co umożliwia pożyteczne - z politycznego punktu widzenia - fałszerstwa. Dzięki niemu możliwe jest skonstruowanie obrazu ułatwiającego sprawowanie władzy, dla którego żadna alternatywa nie jest już potrzebna ${ }^{26}$. Słowa R. Barthesa uzupełnia Bronisław Malinowski, dodając: ,,Mit jest nieustannie odnawiany; każda historyczna przemiana stwarza własną mitologię, która jest powiązana, ale tylko pośrednio z historycznymi faktami” ${ }^{27}$. Władza polityczna, propagując jakiś konkretny mit, dąży do zapewnienia społeczeństwu poczucie bezpieczeństwa. Ludzie poszukują zewnętrznego oparcia nadając jej tym samym autorytet quasi-religijny ${ }^{28}$. Dotyczy to zarówno władzy w reżimach demokratycznych, jak i charyzmatycznych przywódców zdobywających władzę poprzez tworzenie wizji idealnej przyszłości i bazowanie na empatycznym wyczuciu zbiorowych pragnień i nadziei w reżimach nie mających charakteru demokratycznego ${ }^{29}$. Niejednokrotnie mity przybierają wręcz charakter narodowy. Buduje się on najczęściej na szkielecie układu dwubiegunowego „nasi-obcy”, „my-oni”. Powstały w ten sposób, zwykle idealizowany obraz własnej zbiorowości, przyczynia się do umacniania więzi wspólnych wierzeń, przekonań i wartości, opartych o wspólnotę przeżyć. Świadomość mityczna jest czynnikiem pomagającym rozumieć historię, czyli odnosić zdarzenia do ogólnego ładu, interpretować je i tłumaczyćc ${ }^{30}$. Tworząc swój obraz, narody często poszukują argumentów potwierdzających

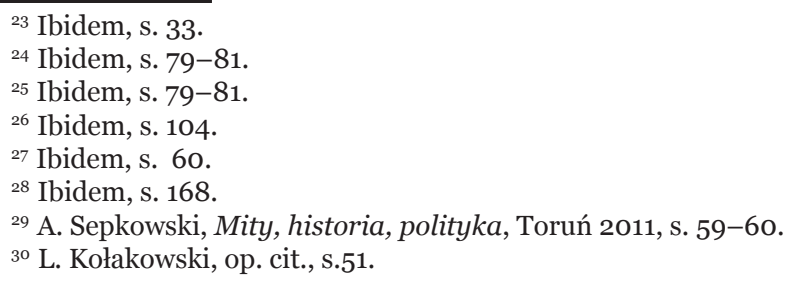


ich inność i wyższość. Wiara ta, obudowana mitami pobocznymi, ma za zadanie kultywować wartości, postawy i zachowania rzekomo tylko temu narodowi przynależne, a w praktyce łudząco podobne do wierzeń kultywowanych przez inne narody.

Według Andrzeja Sepkowskiego narodowy charakter mitów może być odbierany jako łatwość ulegania myśleniu życzeniowemu, wybujała wyobraźnia, łatwość improwizacji, wybujały indywidualizm, czy też zbytnie przywiązanie do symboliki tradycji narodowej ${ }^{31}$. Jednak analizując mity początków poszczególnych narodów M. Eliade przyznaje, że naród nie potrafiący ,udokumentować” swoich początków byłby narodem bez przeszłości, skazanym przez Europę na nieistnienie ${ }^{32}$. Można więc stwierdzić, że gloryfikacja przeszłości, tworzenie narodowych panteonów, stawianie na piedestałach władców służy przetrwaniu, konstruowaniu dumy i potwierdzaniu godności narodu ${ }^{33}$.

\section{NARODZINY WSPÓ£CZESNEGO SERBSKIEGO NACJONALIZMU}

JEDNYM Z KLASYCZNYCH PRZYKŁADÓW PRÓBY PRZEEOŻENIA HISTORYCZNEGO MITU na rzeczywistość polityczną jest odwołanie się przez serbskich nacjonalistów do mitu kosowskiego. We współczesnej Serbii za jeden z kanonicznych tekstów budujących ideologię nurtu narodowego można uznać pochodzące z 1935 r. przemówienie Nikolaja Velimirovicia, zatytułowane Nacjonalizm Świętego Sawy ${ }^{34}$. Stanowi ono przykład rozwijanego wówczas w Europie typowego nacjonalizmu chrześcijańskiego, poszukującego podstawowych wartości w religii i odnoszącego się do wybranych fragmentów historii, w tym przypadku również bitwy pod Kosowym Polem. Już na początku wspomnianego wystąpienia można zauważyć jego główną ideę, którą jest silny wpływ religii prawosławnej na powodzenie narodu serbskiego. Odwołując się do autorytetu św. Sawy, jednego z najważniejszych świętych Serbskiej Cerkwi Prawosławnej, N. Velimirović prezentuje model życia, który każdy Serb powinien kultywować. Św. Sawa całe swoje życie poświęcił Bogu, jednak będąc postacią szczególnie uduchowioną nie szukał samotności i kontemplacji - wychodził do ludzi, których szanował bez względu na pochodzenie. Był obrońcą moralnej i duchowej siły narodu, twórcą jego charakteru. N. Velimirović nacjonalizmem nazywa owoce pracy

\footnotetext{
${ }^{31}$ A. Sepkowski, op. cit., s. 62-64.

${ }^{32}$ S. Filipowicz, op. cit., s. 46.

${ }^{33}$ A. Sepkowski, op. cit. s. 46-47.

${ }^{34}$ N. Velimirović, Nacionalizam Svetoga Save, http://www.scribd.com/doc/288461 o/Vladika-Nikolaj-Velimirovic-Nacionalizam-Svetog-Save, 14.12.2012 r.
} 
św. Sawy nad serbskim narodem: tworzenie kultury, rozumianej jako wyraz narodowych uczuć i zjednoczenie cerkwi narodowej, która przy pomocy jednej wiary i miłości bierze go pod skrzydła. Kościół jest według niego samodzielną organizacją ze swoją władzą. Jej prawdy oparte są na ewangelii, w której można odnaleźć zapisy potwierdzające ogromne znaczenie wybranych przez Boga narodów. Jako przykład N. Velimirović wskazuje słowa wypowiedziane przez Jezusa: „Idźcie i nauczajcie swoje narody”. Dla św. Sawy państwem narodowym była ojczyzna obejmująca terytorium do granic innego podmiotu o charakterze państwa. Podejmowanie walki w celu podboju nowych terenów, zgodnie z zasadami nacjonalizmu chrześcijańskiego, było niedopuszczalne, doprowadzało bowiem do utraty duchowych wartości, poczucia strachu i niepokoju, a także do mieszania się krwi oraz języków. Jedynym rodzajem walki, który nie jest niezgodny z bożą wolą, jest obrona przed napaścią. N. Velimirović przywołuje w tym miejscu właśnie historyczną obronę przed Turkami podczas bitwy na Kosowym Polu. Aby umożliwić narodowi ochronę ojczyzny, Św. Sawa stworzył wojsko zbudowane w oparciu o wspólnotę narodową, które składało się tylko z obywateli, którzy otrzymali błogosławieństwo Cerkwi. N. Velimirović podkreśla, że jego odwoływanie się do idei kultywowanych przez św. Sawę nie jest bezpodstawne.

Mimo że od czasu życia świętego do opublikowania tekstu minęło 700 lat, przedstawione przez niego poglądy pozostały wciąż aktualne. Co więcej, prawdy przez niego propagowane dopiero w czasach współczesnych, według N. Velimirovicia są odnajdywane przez inne narody europejskie. W ten sposób autor nawiązuje przede wszystkim do walki o kościół narodowy, która odbywała się między innymi w Czechach, Holandii, Niemczech, Francji, czy też w Anglii. Jednocześnie próby utworzenia państw narodowych oddzielonych od kościoła poddaje krytyce, gdyż właśnie to oddzielenie jest jego zdaniem przyczyną ich niepowodzenia. Oddzielając kościół od państwa, władza oddziela samą siebie od społeczeństwa. N. Velimirović opisuje także prawdziwego władcę. Głównym kryterium jest spokrewnienie z dynastią wywodzącą się z narodu serbskiego. Na pokrewieństwo to powinny składać się przede wszystkim więzy krwi, języka, ojczyzny, wiary oraz ducha. Władcą spełniającym te wymogi był jego zdaniem m.in. koronowany przez św. Sawę Stefan Nemanjić.

Podsumowując swoje poglądy, N. Velimirović stwierdza, że z perspektywy czasu nadal widoczna jest ogromna praca, którą św. Sawa wykonał na rzecz swojego narodu. To on jest faktycznym twórcą serb- 
skiego nacjonalizmu, uznawanego za najstarszy w Europie ${ }^{35}$. Dlatego, jego zdaniem, stworzony przez niego mit jest lepszy oraz pełniejszy niż te występujące w innych ideologiach nacjonalistycznych, pochodzący z państw europejskich. Wyróżnikiem jest zbudowanie go nie na skalanym wojnami gruncie buntu oraz nienawiści, ale na Świętosławiu. Za tego rodzaju błogosławieństwo Serbowie powinni dziękować przede wszystkim św. Sawie, gdyż to dzięki niemu Serbia mogła działać w oparciu o Cerkiew, symbolizującą niejako jedność ducha i krwi ${ }^{36}$.

\section{MIT KOSOWSKI JAKO INSTRUMENT PROPAGOWANIA IDEI NACJONALISTYCZNYCH}

KONFLIKT DOTYCZĄCY TERENÓW Kosowa I METOCHI jest jednym z najbardziej zakorzenionych w historii Europy sporów. Jego geneza sięga pojawienia się na tym obszarze przodków współczesnego narodu serbskiego. Już sam czas w którym do tego doszło jest kwestią sporną ${ }^{37}$ : niektórzy badacze dopatrują się serbskiej obecności na tych terenach już w pierwszych wiekach naszej ery. Według innych serbscy protoplaści dotarli tam dopiero w VII w., a być może nawet w XII w. ${ }^{38}$

$\mathrm{Na}$ początku XIV w. na kontynencie europejskim rozpoczęła się ekspansja turecka. W 1352 r. zajęto przylądek Gallipoli, w 1361 r. Adrianopol, a następnie dokonali podboju Tracji i Macedonii. Inwazję turecką próbowano powstrzymać, odwołując się do pomocy papiestwa, jednak próby te nie przyniosły żadnego rezultatu ${ }^{39}$. 15 czerwca $1389 \mathrm{r}$. doszło do słynnej bitwy na Kosowym Polu pomiędzy wojskami tureckimi, a broniącą swojego terytorium Serbami. Armia inwazyjna miała znaczną przewagę liczebną nad serbskimi obrońcami, stąd też w sensie militarnym łatwo było wskazać zwycięzcę. Walka zakończyła się całkowitą klęską Serbii, w wyniku czego została ona zmuszona do przyjęcia wieloletniego tureckiego zwierzchnictwa. Na polu bitwy zginęło około 5 tys. Serbów, a 30 tys. zostało wziętych do niewoli tureckiej ${ }^{40}$. Jednym

35 Ibidem.

${ }^{36} \mathrm{~W}$ języku serbskim funkcjonuje takie samo, jedno tylko określenie na Cerkiew i Kościół. Podczas tłumaczenia zastosowano polskie ekwiwalenty.

${ }^{37}$ Różne źródła odmiennie przedstawiają kwestię pierwszeństwa na ziemiach Kosowa, wskazując naprzemiennie Albańczyków bądź Serbów. Szerzej: K. Kubiak, Wojny, konflikty zbrojne i punkty zapalne na świecie, Warszawa 2005, s. 47.

${ }^{38}$ T. A. Emmert, The Battle of Kosovo: Early Reports of Victory and Defeat, http:// web.archive.org/web/20110716072235/http://www.deremilitari.org/resources/articles/emmert.htm, 19.03.2013 r.

${ }^{39}$ A. Mączak, Historia Europy, Kraków 1997, s. 218.

$4^{\circ}$ E. Bujwid-Kurek, Państwa postjugosłowiańskie. Szkice politologiczne, Kraków 2008 , s. 195 . 
z pojmanych był dowodzący wojskiem serbskim książę Lazar, który został następnie zamordowany. Jednak również strona turecka poniosła dotkliwą stratę, gdyż w bitwie poległ sułtan Murad. Należy nadmienić, że samo zwycięstwo nad Serbami otworzyło Turkom drogę do późniejszego, dalszego podboju Europy ${ }^{41}$.

Od czasu klęski na Kosowym Polu Serbowie zaczęli emigrować na północ, a ich miejsce stopniowo zajmowali Albańczycy. Liczba ludności albańskiej zamieszkującej tereny Kosowa pod panowaniem tureckim znacznie się zwiększyła, a przez kolejne stulecia ulegała dalszemu wzrostowi. Procesu tego nie przerwały wojny bałkańskie z początku XX w., ani zjednoczenie ideą wspólnego państwa - Jugosławii. W latach 1948-1981 liczba Serbów zamieszkujących na stałe Kosowo spadła z 37,5 do 14,7\%, a w 1991 r. Albańczycy stanowili już 82,2\% mieszkańców ${ }^{42}$. Kosowo dwukrotnie uzyskiwało statut autonomiczny w ramach Serbskiej Republiki Jugosławii - pierwszy raz w 1945 r. (zniesiony w 1968 r.), drugi w 1974 r. Stosunki serbsko-albańskie pogorszyły się na początku lat osiemdziesiątych XX wieku. W marcu 1981 r. w Prisztinie doszło do demonstracji albańskich studentów i robotników, którzy domagali się przekształcenia Kosowa w siódmą republikę Jugosławii. W odpowiedzi rząd serbski zniósł autonomię Kosowa i wcielił region do Republiki Serbskiej ${ }^{43}$. W 1991 r., a więc w okresie rozpadu Jugosławii, podziemie albańskie przeprowadziło referendum, w którym 99\% Albańczyków opowiedziało się za niepodległością Kosowa. 24 maja 1992 r. wybrali oni swój parlament i prezydenta. Jednak zarówno referendum, jak i przeprowadzone wybory zostały zignorowane przez serbskie władze. Dodatkowo rząd serbski rozpoczął masowe wyrzucanie albańskich studentów z uczelni oraz przyjmowanie na stanowiska urzędnicze tylko obywateli serbskiego pochodzenia. Próby porozumienia Serbów i Albańczyków nie przynosiły rezultatu44. 17 lutego 2008 r. parlament Kosowa jednomyślnie uchwalił deklarację swojej niepodległości. Mimo, że została ona odrzucona przez Serbię, uznało ją 75 państw świata (w tym Polska), a także ONZ. Międzynarodowy Trybunał Sprawiedliwości orzekł, że deklaracja niepodległości

${ }^{41}$ Ibidem.

${ }^{42}$ M. Tanty, Batkany w XX wieku. Dzieje polityczne, Warszawa 2003, s. 358.

${ }^{43}$ Ibidem, s. 360.

${ }^{44}$ W roku 1998 w Prisztinie odbyły się wielotysięczne manifestacje, a rok później Serbowie we wsi Raczak dokonali mordu na 45 Albańczykach; ibidem, s. 359. 
Kosowa nie była nielegalna z punktu widzenia prawa międzynarodowego 45 .

Wzajemna wrogość serbsko-albańska wynika między innymi ze zderzenia się dwóch nacjonalistycznych koncepcji - Wielkiej Serbii i Wielkiej Albanii. Także wzajemne stosunki między ludnością sprzyjają zaognianiu się konfliktu: Serbowie traktują Albańczyków z wyższością, natomiast Albańczycy odbierają Serbów jako okupantów. Istotna jest także różnica religijna - zderzenie serbskiego prawosławia $\mathrm{z}$ dominującym w Albanii islamem ${ }^{46}$. W sporze o Kosowo argumentacja zarówno jednej, jak i drugiej strony opiera się przede wszystkim na płaszczyźnie historycznej. Serbowie podkreślają znaczenie Kosowa jako kolebki swojej państwowości i centrum kultury duchowej. Obywatele Kosowa uznają jednak te dzieje za zbyt odległe, a swoje dążenia dodatkowo wspierają na przysługującym im prawie do samostanowienia.

\section{Mitologizacja bitwy na Kosowym Polu}

Temat Bitwy Na Kosowym Polu poJawiŁ SIE nIE tylKo w dokumentach o tematyce historyczno-politycznej, lecz także stał się jednym z głównych motywów eposu ludowego. Serbskie pieśni epickie opowiadające o obronie przed Turkami były natchnieniem do walki i wspomnieniem narodowej wolności. Te ludowe opowieści charakteryzują się głębokim napięciem dramatycznym i bogatym liryzmem. Przekazywane z ust do ust historie opiewające bohaterskie czyny narodu serbskiego powstały poprzez połączenie czynników historycznych z mitologicznymi. Stanowiły one żywą kronikę wydarzeń, będąc jednocześnie narzędziem narodowej propagandy i sposobem artystycznego wyrażania się 47. Pierwsze wzmianki historyczne dotyczące pieśni, a zarazem ich pierwsze szczątkowe zapisy sięgają XV w. Początkowo utwory były bardzo rozpowszechnione między najmniej wykształconymi warstwami społeczeństwa. Ich ranga wzrosła dopiero w XIX w., gdy zebrał je i opisał badacz folkloru Vuk Karadžić. W nieco zmodyfikowanej formie pojawiły się też one jako partyzanckie pieśni ludowe na terenie Bośni i Macedonii w okresie ich przynależności do Jugosławii ${ }^{48}$.

${ }^{45}$ M. Waehlisch, B. Xharra, 3 lata po niepodległości, Kosowo walczy o uznanie, http://www.stosunkimiedzynarodowe.info/artykul,919,3_lata_po_niepodleglosci_ Kosowo_walczy_o_uznanie, 13.12.2012 r.

${ }^{46}$ M. Tanty, op. cit., s. 359.

${ }^{47}$ M. Jakóbiec, Jugosłowiańska epika ludowa, Wrocław 1948, s. 9-14.

${ }^{48}$ Ibidem, S. 20-21. 
Spośród pieśni historycznych możemy, wzorem V. Karadžicia, wyróżnić dziesięć cyklów. Jednym z nich jest cykl kosowski+9, do którego należą pieśni opisujące wydarzenia z czerwca 1389 r. Bitwa rozgrywa się zasadniczo poza sceną dramatów, ale stanowi ich niezbędne i oczywiste łło $^{50}$. Akcja rozgrywa się wokół samej walki, skupiając się na odbiorze zdarzeń z perspektywy prostych ludzi. Przedstawiając wydarzenia polityczne i historyczne, śpiewacy zbliżali się do ludu i ukazywali jego emocje związane z bitwą i klęską ${ }^{51}$. Przykładem pieśni z cyklu kosowskiego jest Śmierć matki Jugoviciów ${ }^{52}$. Poetyckie opowieści pobudzały narodową dumę, a także pragnienie zemsty. To one de facto doprowadziły do ukształtowania się mitu kosowskiego $^{53}$. Zawarta w utworach prawda historyczna jest tylko podstawą, która rozwija się wraz z inwencją opowiadacza. Słuchacze mieli być poruszeni, zlęknieni, ale także pokrzepieni do walki, silnie odczuwać przynależność do narodu serbskiego. Opierając się na tych informacjach można stwierdzić, że to nie same wydarzenia z 1398 r. doprowadziły do tak trwałego przywiązania Serbów do Kosowa, lecz doszło do tego dzięki mitom, przekształconym opowieściom przekazywanym z pokolenia na pokolenie ${ }^{54}$.

\section{MIT KOSOWSKI JAKO NARZĘDZIE POLITYKÓW}

W CIĄGU OSTATNICH DZIESIĘCIOLECI POSŁUGIWANIE SIĘ MITAMI zapisanymi w kulturze przybrało postać strategii stosowanej przez serbskie elity polityczne. Walka o umocnienie władzy w regionie oraz usprawiedliwianie swoich działań przeniosła się na front kulturalny. Taka tendencja była widoczna między innymi w wypowiedziach Slobodana Miloševicia. W sześćsetną rocznicę bitwy na Kosowym Polu S. Milošević zwrócił się do narodu, serbskiego podkreślając istotne znaczenie mitu

\footnotetext{
49 Ibidem, s. 38.

${ }^{50}$ Ibidem, s. 40-41.

${ }^{51}$ J. Benešić, Jugosłowiańska poezja ludowa, Warszawa 1938, s. 83.

${ }^{52}$ Pieśń opowiada o kobiecie, która pozostała w domu wyprawiając na pole bitwy męża i swoich dziewięciu synów. Oczekując ich powrotu pełna niepokoju ubłagała Boga, aby ten dał jej wzrok sokoła i łabędzie skrzydła, by tym sposobem mogła wzbić się ponad Kosowo Pole. Bóg wysłuchał prośby, jednak niestety, kobieta przelatując nad pobojowiskiem ujrzała martwe ciała swoich bliskich. Matka dzielnie zniosła ból zadany jej przez los i powróciła do domu, aby pocieszać żony zmarłych synów. Jednak gdy kruk przyniósł w dziobie rękę zmarłego na polu bitwy najmłodszego dziecka, z żalu pękło jej serce.

${ }^{53}$ J. Benešić, op. cit., s. 84.

${ }^{54}$ Warto wspomnieć, że do dziś Cykl kosowski należy do serbskiego kanonu lektur szkolnych.
} 
kosowskiego. To, że dziś trudno określić, co jest prawdą historyczną o Kosowie, a co stanowi tylko legendę, jest według przywódcy sprawą drugorzędną. Nie można też określić, czy przegrana w boju stanowiła klęskę, czy ostatecznie okazała się serbskim zwycięstwem. Heroizm kosowskich bohaterów przez sześć wieków stanowił inspirację i nie pozwalał zapomnieć o niegdysiejszej potężnej, odważnej i dumnej armii. Obrona obszaru Kosowa była jednocześnie obroną Europy, europejskiej kultury, religii i społeczeństwa. S. Milošević swoje przemówienie zakończył słowami: „Niech pamięć o bohaterskim Kosowie żyje wiecznie!, Niech żyje Serbia! Niech żyje Jugosławia! Niech żyje pokój i braterstwo między narodami!" 55 .

S. Milošević dążył do tego, aby stać się swoistym wodzem narodu, następcą poległego w bitwie, historycznego księcia Lazara. W działaniach propagandowych język folkloru i epicka tradycja ludowa okazały się niezwykle skuteczne. Motywy pobudzające patriotyczne emocje przeniknęły do kultury masowej i zawładnęły zbiorową wyobraźnią ${ }^{56}$. Ivan Čolović w eseju Folklor $i$ polityka przedstawia przykład propagandy opartej na folklorze pochodzący z ,,pewnego rękopiśmiennego eposu z okolic Žagubicy":

Slobodanie, szablo nasza ostra, Nowej bitwie na Kosowie sprostaj!

Zawołamy chlubę Strahinjiciów, Jug Bogdana, Dziewięć Jugoviciów, Boška który sztandar nasz poniesie szablą swoją Kosowo podniesie.

Niech gorąca krew w Kosowie płonie niech rozkwitną kosowskie piwonie!

Powiedz tylko, że czas boju bliski, a polecimy jak ostre pociski ${ }^{57}$.

W tym krótkim fragmencie znajdziemy wszystko, co łączy się z kosowskim testamentem - jest bohater ludowy ban ${ }^{58}$ Strahinjić, który wraz z dziewięcioma synami zginął w bitwie z Turkami, a także kosow-

55 Speech Slobodan Milošević, 28 june 1989, http://emperors-clothes.com/milo/ milosaid.html\#2, 13.12.2012 r.

${ }^{56}$ M. Dąbrowska-Partyka, Gusle, knindže i civilno društvo. Retoryka serbskich tekstów o tematyce narodowej, http://postjugo.filg.uj.edu.pl/Gusle.pdf, 17.12.2012 r., s. 6.

57 Ibidem, s. 5 .

${ }_{5}^{8}$ Ban - zarządca okręgu wojskowego w historycznej Serbii. 
skie piwonie, które swoim corocznym kwitnieniem wyznaczają czas współczesnego odnawiania kosowskich ślubów ${ }^{59}$.

\section{Mit Kosowski W KULTURZE MASOWEJ}

WE WSPÓ£CZESNEJ SERBSKIEJ KULTURZE MASOWEJ MOŻEMY odnaleźć bardzo wiele połączeń folklorystycznych inspiracji z intencjami oraz celami politycznymi współczesnego nacjonalizmu. Turbofolk, gatunek muzyczny charakteryzujący się nieskomplikowanymi melodiami i prostymi tekstami, pełen jest tego rodzaju nawiązań. W latach 9o. to właśnie w tych bardzo popularnych piosenkach odrodziła się bohaterska pieśn epicka. Nacjonaliści serbscy niejako odnowili klasyczny folklor oraz zastosowali go w służbie nowej sytuacji politycznej, jak na przykład w wydanej w 1989 r. piosence Gordany Lazarević Vidovdan:

Patrzę w niebo, mijają wieki

Starych wspomnień jedyne leki

Gdziekolwiek pójdę, znów wracam do Ciebie

Nikt nie wyrwie Kosowa z mojej duszy

Vidovdan

Jak wieczny płomień w naszych sercach,

Kosowska bitwa zostaje prawdziwa $(. . .)^{60}$.

W ostatnich kilkunastu latach zaangażowanie muzyków w sprawy narodowościowe wcale nie zmalało. Wiele młodych zespołów reprezentujących rozmaite gatunki muzyczne w swoich tekstach demonstruje poczucie solidarności i wspólnoty narodowej. Młodzi przedstawiciele narodu jako oręża swojej walki używają słów. Powstały w 1966 r. zespół „357” znany jest ze swoich kontrowersyjnych tekstów, które są powodem jego rzadkiej obecności w mediach. Jednak w kręgu młodych serbskich nacjonalistów grupa odnosi sukcesy, wykonując takie utwory, jak Jedna jest Serbia czy Gazimestan ${ }^{61}$. W swoich, nierzadko wulgarnych, tekstach zespół wychwala kosowskich bohaterów, wyznając jednocześnie głęboką, wieczną miłość do swojej Matki Serbii i deklarując gotowość oddania za nią swojego życia ${ }^{62}$. Innym zespołem

${ }^{59}$ Ibidem, s. 5-6.

${ }^{60}$ Vidovdan - dzień św. Vida, w Serbskiej Cerkwi Prawosławnej ważne święto religijne, przypadające 28 czerwca, a więc w dzień bitwy na Kosowym Polu. Tłumaczenie tekstu piosenki M. Kobierska.

${ }^{61}$ Nazwa pomnika upamiętniającego bitwę na Kosowym Polu.

${ }^{62} \mathrm{Na}$ kosowskq nutę, http://autonom.pl/index.php/news/informacje/1577-na-kos 
podejmującym podobną tematykę jest założony w 1999 r. Beogradski Sindikat. Grupa licząca jedenastu raperów jest jedną z najbardziej znanych formacji w kraju. Ich teksty koncentrują się na tematach politycznych i krytyce władzy. Członkowie Sindikatu nadają swoim utworom wyraźne akcenty narodowe. Ich najbardziej znany utwór Nikt nie może wiedzieć przedstawia negatywny stosunek części młodych Serbów do ogłoszonej w 2004 r. autonomii Kosowa ${ }^{63}$.

Serbska myśl nacjonalistyczna w dużej mierze rozwija się w oparciu o mit bitwy na Kosowym Polu. W oficjalnych dokumentach propagatorzy idei nacjonalizmu na scenie politycznej nie posługują się bezpośrednio nim jako argumentem, jednak pewne wystąpienia polityków wskazują na silną więź łączącą mit kosowski z ich nacjonalistycznymi poglądami. Poza sceną polityczną kwestia historycznej bitwy jest stale obecna, np. można ją odnaleźć zarówno w tekstach piosenek jak i wśród wyrażanych na forach internetowych poglądów społeczeństwa zwykłych Serbów ${ }^{64}$. Kultura stała się narzędziem, za pomocą którego legitymizuje się strzeżenie narodowego terytorium ${ }^{65}$. Jest ona dziś pretekstem do wykluczenia i nietolerancji. Będąc uprzywilejowaną ostoją odrębności i jedności, akcentuje jednocześnie różnicę między „nami” i „nimi”. Podczas wojny w byłej Jugosławii argument obrony kultury, nie tylko narodowej, lecz także europejskiej i ogólnoludzkiej, był jednym z najczęściej wymienianych powodów przyłączenia się do walk. Brak okazywania w wystarczającym stopniu przynależności do tradycji i wartości narodowych narażał na gniew zagorzałych nacjonalistów ${ }^{66}$.

Narodowa przestrzeń duchowa, wyznaczona śladami historii oraz kultury przynależy do narodu nawet w momencie, w którym nie stanowi ona fizycznej części jego państwa. Z tej przyczyny nieznajdujące się już w serbskich granicach Kosowo uznawane jest przez Serbów za „ziemię świętą.” Wyjątkowość tego regionu jest niejako doznaniem w sferze transcendencji, a nie rzeczą realną, pozwalającą odczuwać przynależność do niej także, gdy znajduje się ona pod rządami innego narodu. Aby ukazać, że traktowanie terenów Kosowa jako miejsca świętego nie jest tylko symbolicznym gestem, można odwołać

owska-nute, $18.12 .2012 \mathrm{r}$.

${ }^{63}$ Ibidem.

${ }^{64}$ Jako przykład można wskazać internetowe forum serbskich nacjonalistów, http:// forum.srpskinacionalisti.com/, 17.12.2012 r.

${ }^{65}$ I. Čolović, Bałkany - terror kultury, Wołowiec 2007, s. 7.

${ }^{66}$ Ibidem, s.10-14. 
się do listu otwartego skierowanego w 1998 r. przez Wszechserbski Sobór Cerkiewo-Narodowy do Serbskiej Cerkwi Prawosławnej, w którym kosowscy Serbowie nawoływali do jak najszybszego oficjalnego ogłoszenia Kosowa i Metochii świętą ziemią serbską ${ }^{67}$.

Mocą polityków jest posiadanie monopolu władzy nad świętościami narodowymi, których zobowiązują się strzec i które utrzymują w stanie gotowości, aby skorzystać z nich kiedy pojawi się taka potrzeba. Mit bitwy na Kosowym Polu zajmuje szczególne miejsce w zbiorze populistycznych baśni opowiadanych narodowi. Samo przywołanie motywu starcia z Turkami nadaje dowolnemu kontekstowi o wiele więcej znaczący wymiar, przywołuje patos i poczucie dumy z narodowej przynależności do historycznej wspólnoty. Wydarzenia współczesne oraz te z przeszłości zyskują wspólny wymiar, tworząc opowieść, której bezkompromisowo najważniejszym aktorem jest naród serbski $^{68}$.

\section{ZAKOŃCZENIE}

W ARTYKULE ZAPREZENTOWANO OBECNOŚĆ MITU KOSOWSKIEGO w serbskiej myśli nacjonalistycznej. Celem było zbadanie hipotezy o obecności historycznej bitwy na Kosowym Polu jako ważnego elementu współczesnej serbskiej polityki, w oparciu o który Serbia stara się budować swoją narodową tożsamość. Przeprowadzona analiza pozwoliła na odnalezienie wybranego wątku na wielu płaszczyznach powiązanych przede wszystkim z ideą nacjonalizmu. Wskazany w artykule materiał badawczy stanowi zaledwie część możliwych do zbadania materiałów, a sam temat ma być impulsem do być może innej perspektywy w ocenie postaw współczesnych Serbów. W odniesieniu do omawianego mitu można podkreślić słuszność stwierdzenia, że swoista mitologia historyczna może odgrywać znaczącą rolę w kreacji polityki państw nawet na początku XXI w. Ukazano także związek pomiędzy serbskimi postawami narodowymi a wydarzeniem, którego przebieg podlegał przez wieki procesowi przekształcania w mit. Wyniki analizy, a zwłaszcza jej ostatniej fazy, można potraktować jako naukowe dowiedzenie obiegowej opinii o częstym pojawianiu się mitu kosowskiego w wielu dziedzinach życia serbskiego społeczeństwa. Mit kosowski jest nadal żywo obecny w serbskiej myśli nacjonalistycznej. Należy jednak przyjąć, że wraz z upływem czasu, a przede wszystkim wzrostem popularno-

\footnotetext{
${ }^{67}$ Ibidem, s. 63-64.

${ }^{68}$ Ibidem, s. 56-57.
} 
ści europejskiej idei zjednoczenia, tendencja ta może stracić na intensywności. Można także sądzić, że ewentualne wyrugowanie mitu bitwy na Kosowym Polu z serbskiej świadomości nie nastąpi gwałtownie, a być może nie dojdzie do tego wcale. Warto zauważyć, że aktualne europejskie trendy oraz kryzys gospodarczy mogą, wręcz przeciwnie, doprowadzić do wzmocnienia pozycji mitu kosowskiego wśród propagatorów idei nacjonalistycznych.

\section{SUMMARY}

The ARTICle Discusses the PRESENCE OF THE SO-CALled Kosovo MYTH that can be traced in Serbian nationalist thought. The theory of myths which has been analysed in the course of the article has ultimately proven that the Battle of Kosovo Field shall be given a quality of a Myth. Moreover, thanks to a reference to the history of Serbian nationalism, a gross importance in building a sense of nationhood has been confirmed with regard to the aforementioned Myth. An in-depth analysis of the selected examples of the use of myths in culture has shown significant emotional attachment of Serbian people to myths. What is more, it has been confirmed that myths are exploited also on the political scene which contributes to a strong relationship between a mythological memory of the Battle and a shape of Serbian nationalist stances.

\section{Nota O AUTORCE}

Martyna Kobierska [martyna.kobierska@gmail.com] - studentka I roku studiów II stopnia na kierunku Stosunki Międzynarodowe na WNPiD UAM. Absolwentka politologii na tym samym wydziale oraz Filologii Chorwackiej i Serbskiej na Wydziale Filologii Polskiej i Klasycznej UAM. 